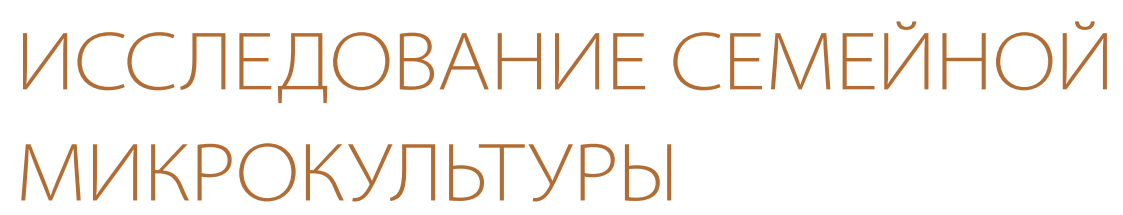

\title{
THE STUDY ON FAMILY MICROCULTURE
}

\section{Горелкина Мария Александровна}

Магистрант кафедры психологии образования ФГБОУ ВО «Московский педагогический государственный университет»

E-mail: mgorelkina@yandex.ru

Аннотация. В данной статье семья и ее микрокультура рассматривается как транслятор норм, правил поведения, семейного быта, под влиянием которых в человеке закладываются системы отношений к собственной жизни, к социуму, к вселенной, то есть смысложизненные человеческие ценности. Основное внимание уделяется структуре микрокультуры. Выделены основные блоки, составляющие микрокультуру. Разработан авторский опросник для исследования семейной микрокультуры.

Ключевые слова: семейная микрокультура, семейный уклад, структура семейного быта, авторский опросник, семейные традиции.

\section{Gorelkina Maria A.}

Student in the master's program at the Department of Psychology of Education, Moscow Pedagogical State University E-mail:mgorelkina@yandex.ru

Abstract. In this article, the family, and its microculture, is considered as a translator of norms, rules of behavior, family life, under the influence of which a person obtains a system of relations to their own life, to society, to the universe, in other words, life-meaning human values. The main attention is paid to the structure of the microculture. The main blocks that make up the microculture are highlighted. The author's proprietary questionnaire for the study of family microculture is developed.

Keywords: family microculture, a family's way of life, structure of a family's life, proprietary questionnaire, family traditions. 
Несмотря на образование, городской быт и жизнь в мегаполисе, мы наследуем и формируем жизненные ценности от своих родителей, а они в свою очередь, - от бабушек и дедушек [1, с. 5].

Наиболее важная роль в формировании жизненных ценностей отводится семейному микроклимату, или семейной микрокультуре. Под микрокультурой семьи мы понимаем культурно-историческую модель, в которой в результате естественного повседневного и ритуализированного общения происходит усвоение человеком информации о существющих моделях, нормах поведения [2, с. 222-224].

При высоком интересе к семье и семейным средствам воспитания малоизученным остается понятие семейной микрокультуры как скрытому, не регламентируемому влиянию семейного жизненного уклада на накопление человеком социального опыта. Между тем потребность в осмыслении семейной микрокультуры и ее структуры очевидна не только из-за возрастающего интереса к семейному прошлому, но и из-за переосмысления семейных культурных практик и анализа форм внутрисемейного взаимодействия.

Изучение микрокультуры семьи отсылает к теоретическому анализу семейного быта, семейного прошлого, верований и установок, религиозных семейных практик, традиций и обрядов, то есть традиционной духовной культуры русских семей [3, с. 1].

Исследования Е. Е. Сапоговой, И. А. Разумовой позволили сформулировать вывод, что семейная микрокультура складывается из следующих блоков: семейные традиции, пространственно-предметный мир семьи, семейно-родственные связи, история рода [2, с. 223; 4, с. 4].

Наблюдение за семейным бытом показывает, что существуют разные варианты семейной микрокультуры. И. А. Разумова отмечает, что фактором их формирования служит дифференциация семей по комплексу признаков [4, с. 319].

Создание параметров для классификации семейных групп представляется одной из перспективных проблем. На основании выявленных блоков мы разработали приведенный в конце статьи опросник.

В разработке опросника мы опирались на монографию И. А. Разумовой «Потаенное знание современной русской семьи. Быт. Фольклор. История» [4], поскольку в ней наиболее полно представлены анализ компонентов микрокультуры семьи, механизмов внутрисемейного взаимодействия и факторов формирования семейной картины мира.

Первый блок, входящий в семейную микрокультуру, - это «Семейные традиции». Если какое-то занятие или действие повторяется неоднократно, переходит от одного поколения к другому, то оно становится традицией, оказывающей влияние на характер внутрисемейных отношений. Традиции - это принятые стандарты поведения, обычаи и взгляды, которые ребенок понесет в свою будущую семью [4, с. 8, 13].

Проведенные исследования подтверждают, что наблюдаются явные тенденции к возобновлению и сохранению традиций. Традиции и обряды обладают высоким социализирующим потенциалом, а совместный семейный досуг, проводимый согласно традициям, служит могучим стимулом для развития личности ребенка.

Поэтому на первом этапе разработки опросника мы выделили следующие критерии, описывающие приобщение к семейным традициям:

1) появление традиций (целенаправленно ввели в уклад жизни, переходят из поколения в поколение, появились сами собой); 
2) виды традиций (семейные трапезы, блюда);

3) приобщение к традициям (нормы, правила, воспитательные беседы, личный пример).

Итак, традиции формируют собственное семейное микрокультурное пространство, поэтому для составления опросника мы выявили наличие и виды традиций (традиции, связанные с праздниками, традиции «выходного дня», традиции, связанные с достижениями).

Второй блок - «Семейно-родственные связи».

С одной стороны, семейно-родственные связи дают человеку необходимую систему координат для определения собственного устойчивого места в социуме, а с другой - индивидом осознается собственная уникальность на фоне семейного сходства [4, с. 31].

Семейно-родственные связи понимаются, прежде всего, как характерологические, психические или физические отличительные признаки, присущие семейной группе. Утверждение сходства или несходства с родственниками - важный структурный компонент формирования личности, способствующий самоутверждению. Констатация родственного сходства объясняется с разных точек зрения: путем собственного наблюдения или ссылкой на чужое мнение, набором устойчивых фраз, например, «одно лицо с мамой».

Родственное сходство в семьях наследуемо. От поколения к поколению передается разнообразный спектр качеств: темперамент, характер, коммуникабельность, способности. Профессиональные склонности и хобби тоже рассматриваются как наследуемые. Связи через поколение выявляются очень четко.

В блок «Семейно-родственные связи» входят пересказы и семейная интерпретация сновидений. Толкование снов, как и интерпретация примет, - часть воспитывающей микросистемы семьи («не к добру», «К известию»). Имянаречение во многих семьях весьма ценно и приобретает символический характер: имена являются важным фактором организации семейно-родственных групп, личные имена «служат стабилизатором семейнородственных коллективов вследствие самой природы имени, являющегося одновременно порождением и условием межличностных взаимоотношений» [4, с. 31]. Микрокультура динамическая система. В семейно-родственных связях постоянно происходят изменения в соответствии с фазами жизни семьи, переменой семейных ролей.

При составлении опросника для исследования микрокультуры семьи мы выделили следующие категории семейно-родственных связей:

1. Фамильное сходство и наследственность: внешние и внутренние атрибуты родства (способности, темперамент), наследственность профессий.

2. Семейные закономерности и личные судьбы (повторение, совпадение в судьбах родственников, наречение детей именами старших родственников).

3. Эмоционально-семейный код (предчувствия, семейные приметы).

4. Символика сновидений (семейное толкование сновидений в устной и книжной традиции).

Третий блок в структуре микрокультуры семьи - это «Пространственно-предметный мир».

Семейно-родственное единство соответствует пространственному, так как совместное проживание является основанием отождествления с семейной группой. Единство 
семьи поддерживается, прежде всего, местом совместного пребывания - «родовым домом» или «родиной» проживания. Самым эффективным средством избежать ссор с родственниками считается пространственное разъединение в виде автономизации семейного жилья молодой пары, переезда. Дом для человека воспринимается как защита, убежище, где можно спрятаться и укрыться от невзгод [5, с. 7].

Наличие символических мест в доме является компонентом семейного жизненного уклада. Символическим местом может служить «дверной косяк» с зарубками для обозначения роста и возраста детей, стол или телевизор, объединяющий всю семью. Источники тепла и света также являются универсальными предметами, посредством которых семья сплачивается. Это могут быть настольные лампы, камины. Эти домашние атрибуты также служат символами домашнего уюта. Часы занимают особое место в «пространственнопредметном» мире семьи. Часы в доме символизируют жизненную энергию, отсчитывают необратимое время [4, с. 124].

В любой семье есть предметы, связывающие поколения и свидетельствующие о глубине семейной памяти. Круг предметов-реликвий очень разнообразен. Это могут быть фотографии, ювелирные украшения, ордена, картины, статуэтки, иконы, прядь волос, первый выпавший зуб и обереги. У каждого предмета-реликвии есть своя история, связанная с рождением или смертью, юбилеями, торжествами и другими памятными датами.

Для опросника нами были выделены компоненты предметно-пространственного блока:

1. Интерьер и символика «домашности» (наличие своего места за столом; дверной косяк с обозначением возраста и роста детей, как символическое место в доме; телевизор, лампа, как место сбора родственников).

2. Семейная реликвия (обереги, талисманы, вещи, хранимые как память о прошлом).

3. Семейная фотография (семейные альбомы, как рассказ об истории рода).

4. Дом в семье («дом» - синоним слова «родина», «родовой дом в структуре «семейного коллектива»).

Четвертый блок, характеризующий семейную микрокультуру, - это «История рода $b$ генеалогических преданиях и семейных устных рассказах (меморатах)».

Рассматриваемое текстовое пространство микрокультуры отображается в семейных биографических рассказах, преданиях, устных рассказах, письменных зафиксированных семейных воспоминаниях (хроникатах), школьных сочинениях [4, с. 184-186].

Семейные биографии и воспоминания представляют описание истории семейного рода, ориентируют в жизненном пути. Адресуются реальным или символическим потомкам. Основная функция повествовательных текстов - дидактико-воспитательная. События, вокруг которых аккумулируется повествование, зачастую связаны с первопредками, с «родовой местностью», с «точками отсчета семейной исторической памяти», с констатацией этнической принадлежности, с преданиями о происхождении фамилии. Особое место в семейных текстах занимают рассказы о распаде и создании семьи. Они занимают центральное положение в семейно-биографических текстах. Повествования о распаде или воссоединении семьи, как пишет И. А. Разумова, составляют важную часть в семейной 
истории. Многообразие семейных текстов репрезентирует семейный исторический опыт при осмыслении родства и семейных связей [4, с. 245].

Исследуя блок «История рода в генеалогических преданиях и семейных меморатах», мы опирались на следующие опорные категории:

1. Семейный и исторический нарратив (круг текстов, в которых вербализуется история семьи, например, семейный биографический рассказ, который зачастую рассказывает прародитель; наличие семейных дневников, материнских записных книг, сборник школьных сочинений.

2. Начало семейной памяти (история родины предков наличие «точек отсчета» семейной памяти, давнего известного «первопредка» или «первособытия», самый дальний предок это прабабушка или прадедушка, устные семейные рассказы о создании/распаде семьи).

3. Предания о происхождении фамилии (объяснение происхождения, выбор имени происходит согласно семейной традиции).

4. Существование семейного архива (документы, справки, вырезки из газет, почетные грамоты, удостоверения).

Таким образом, наш опросник состоит из четырех блоков:

1. Семейные традиции.

2. Семейно-родственные связи.

3. Пространственно-предметный мир.

4. История рода в генеалогических преданиях и семейных меморатах.

Каждый блок содержит 10 утверждений, предназначенных для сбора информации о семейных традициях, о родственных взаимоотношениях, об истории семейного рода.

Всего опросник состоит из 40 утверждений.

\section{ТЕКСТ ОПРОСНИКА ДЛЯ РОДИТЕЛЯ}

Уважаемый родитель!

Просим Вас принять участие в исследовании микрокультуры семьи.

Выберите варианты ответа, наиболее соответствующие Вашему мнению, отметьте их знаком «+» или подчеркните.

1. В нашей семье существуют традиции, связанные с праздниками.

2. Нашей семье присущи не только внешние, но и внутренние атрибуты родства (способности, темперамент, хобби).

3. Мой дом - это место, куда я могу прийти с любыми своими проблемами.

4. В нашей семье хранятся семейные дневники (материнские записные книги, сборники школьных сочинений и т. п.).

5. В нашей семье присутствуют традиции «выходного дня».

6. В нашей семье высока частота наследственности профессии.

7. Особенностью нашей семьи является то, что за столом каждый сидит на своем месте.

8. В нашей семье существует ряд текстов, вокруг которых вербализуется история семьи. Например, семейный биографический рассказ и т. п.

9. В нашей семье присутствуют традиции, связанные с достижениями.

10. У меня и моего ребенка одна точка зрения на многие вещи. 
11. Наша семья часто собирается за столом для разговоров.

12. Я знаю происхождение нашей фамилии или были попытки это выяснить.

13. Наши семейные традиции переходят из поколения в поколение.

14. В нашей семье имеются повторения, совпадения в судьбе родственников.

15. В нашей семье есть дверной косяк с обозначением возраста и роста детей.

16. В нашей семье выбор имени происходит согласно традиции.

17. Мы целенаправленно ввели семейные традиции в уклад жизни.

18. Мы с родственниками не только физически, но и психически ощущаем себя родными друг другу.

19. Часы в нашем доме не только отсчитывают время, но и являются признаком уюта и «домашности».

20. В нашей семье существует семейный архив (документы, справки, вырезки из газет, почетные грамоты, удостоверения и т. п.).

21. Традиции нашей семьи появились сами собой.

22. Наречение детей именами старших родственников - устойчивая традиция нашей семьи.

23. У нас есть любимое место сосредоточения семьи (это может быть кухня, телевизор и т. п.).

24. В нашей семье все знают историю самого дальнего предка - это может быть прабабушка или прадедушка (его род занятий, где он жил и т. п.)

25. Приобщение ребенка к жизненным ценностям происходит через нормы и правила, которых должны придерживаться все члены нашей семьи.

26. В нашей семье принято делиться впечатлениями о сновидениях.

27. В нашей семье есть вещи, хранимые как память о прошлом. Например, иконы, книги, свадебное платье и т. п.

28. Я знаю и интересуюсь родиной своих предков.

29. В нашей семье есть фирменные семейные блюда, преходящие из поколения в поколение.

30. У нас в семье одна и та же судьба, мы все - отражение друг друга.

31. Семейный альбом в нашей семье - это рассказ об истории рода.

32. Устные семейные рассказы о создании семьи передаются из поколения в поколение.

33. Я хочу, чтобы традиции моей семьи переняли мои дети в свои будущие семьи.

34. К нашей семье можно отнести утверждение: «Мы понимаем друг друга без слов».

35. В нашей семье есть генеалогическое древо или мы планируем его создать.

36. Рассказы о знаменательных расставаниях и встречах составляют не самую многозначительную, но важную часть семейной повествовательной истории.

37. В нашей семье приобщение детей к семейным ценностям происходит через личный пример.

38. В нашей семье существует комплекс эмоциональных реакций, обозначаемых как «предчувствие».

39. Семейная библиотека - это атрибут нашей семьи.

40. В нашей семье семейная история (автобиография) передается из уст в уста.

\section{Список литературы}

1. Адонъева С. Б. Символический порядок. М.: Амфора, 2011. 90 с.

2. Сапогоßа Е. Е. Культурный социогенез и мир детства: учеб. пособие для высш. шк. М.: Академ. проект, 2004. 496 с.

3. Преснякова-Осипова И. В. Образ и качество жизни семьи // Власть. 2013. № 5. C. 152-155. 
4. Разумова Е. А. Потаенное знание современной русской семьи. Быт. Фольклор. История. М., 2001. 375 с.

5. Осорина М. В. Секретный мир детей в пространстве мира взрослых. СПб.: Питер, 2016. 304 c.

6. Богуславский M. В. Современная стратегия модернизации российского образования: историко-педагогический контекст // Изв. Волгоградского гос. пед. ун-та. 2014. № 6 (91). С. 43-47.

\section{References}

1. Adonieva S. B. Simvolicheskiy poryadok. Moscow: Amfora, 2011. 90 p.

2. Sapogova E. E. Kulturnyy sotsiogenez i mir detstva: ucheb. posobie dlya vyssh. shk. Moscow: Akadem. proekt, 2004. 496 p.

3. Presnyakova-Osipova I. V. Obraz i kachestvo zhizni semyi. Vlast. 2013, No. 5, pp. 152155.

4. Razumova E. A. Potaennoe znanie sovremennoy russkoy semyi. Byt. Folklor. Istoriya. Moscow, 2001. 375 p.

5. Osorina M. V. Sekretnyy mir detey v prostranstve mira vzroslykh. St. Petersburg: Piter, 2016. 304 p.

6. Boguslavskiy M. V. Sovremennaya strategiya modernizatsii rossiyskogo obrazovaniya: istoriko-pedagogicheskiy kontekst. Izv. Volgogradskogo gos. ped. un-ta. 2014, No. 6 (91), pp. 43-47.

\section{Интернет-журнал}

«Проблемы современного образования»

2020, № 2

Статья поступила в редакцию 05.10.2019

The article was received on 05.10.2019 